\title{
Research Journal of Animal and Veterinary Sciences
}

2018 July; 10 (2): pages: $28-37$

DOI: 10.22587/rjavs.2018.10.2.4

\section{Studies on the skin and wool fibres of Barki sheep fed on protected lysine and methionine}

\author{
Naglaa. S. Badawy and W. A. Ramadan \\ Wool Production and Technology Department, Animal and Poultry Production Division, Desert Research Center, Cairo, Egypt \\ *Corresponding Author: Naglaa. S. Badawy, Wool Production and Technology Department, Animal and Poultry Production Division, Desert Research Center, \\ Cairo, Egypt, Email: nagla.salem@ @otmail.com
}

Received date: 15 May Accepted date 14 June Online date: 30 June

Copyright: () 2018 Naglaa, S. and Ramadan, W. A., This is an open-access article distributed under the terms of the Creative Commons Attribution License, which permits unrestricted use, distribution, and reproduction in any medium, provided the original author and source are credited.

\begin{abstract}
Twenty-four adult Barki ewes (non-pregnant) aged 3-4 years with an average body weight of $28.95 \pm 1.37 \mathrm{~kg}$ was used in the study at Maryout Research Station, Desert Research Center. The present work was designed to evaluate the effect of feeding rumen protected amino acids, methionine or/and lysine on some wool follicle structures, skin amino acids as well as the wool fibres changes of Barki ewes. The study was carried out from September 2016 to February 2017. The histological study of the wool follicle in the skin of Barki ewes revealed that, it consisted mainly of outer and inner root sheaths. The increased values of the external diameter and the wall thickness of both primary and secondary wool follicles resulted in from the mixture have an ascending higher value in the lysine group followed by methionine which exhibited the greatest value while the internal diameter recorded a noticeable decrease in the methionine group followed by the other two groups. Histochemically, the general proteins were more abundant in the outer root sheath than in the inner root sheath of both primary and secondary wool follicles. In addition, all the experimental groups were exceeded the control group in the contents of general proteins especially in the methionine group which recorded the greatest amount of the proteins followed by the lysine group. The determination of the amino acid in the skin samples showed that, the addition of rumen protected amino acids (methionine or/and lysine) to the sheep nutrition recorded a variable increase in the content of some essential and non-essential amino acids in the skin of the experimental groups rather than the control group. The methionine group exhibited a significant increase in the content of all amino acids followed by the lysine group. The wool fibres produced from both primary and secondary wool follicles recorded an increase in their diameters rather than the control group especially in methionine group which recorded a significant increase in the fibre cross sectional area, fibre volume, fibre length growth rate, clean wool production, medulla thickness and the percentage of kemp fibres. Also, it recorded a significant decrease in crimp frequency and the percentage of the fine fibres rather than the control group.
\end{abstract}

Keywords: Wool follicle structure, skin amino acids, wool characteristics, Barki ewes.

\section{INTRODUCTION}

Provision of nutrients in balanced form and required amounts is essential to meet the productive targets in livestock. Protein is an important limiting nutrient in ruminants because it plays a pivotal role in growth, production and reproduction of farm animals. Amino acids have versatile and important physiological functions beyond their roles as the building blocks of protein (Wu et al., 2014). Thus, dietary non-essential and essential amino acids are necessary for the survival, growth, development, reproduction and health of animals. Also, nature and level of dietary protein determines the supply of both physiologically and dietary essential amino acids in animals. In ruminants, protein requirements are two folds; to support the anaerobic eco system fermentation in the rumen in which, a portion of dietary protein is degraded in the rumen (rumen degradable protein) and the rest escape from ruminal degradation (rumen undegradable protein), the rumen degradable protein is used to support the growth of anaerobic bacteria and thus profile of microbial protein along with the nature of rumen undegradable protein determines the availability of dietary and physiologically essential amino acids in ruminants to meet the animal needs.

The amount of available amino acids containing sulfur is one of the most important nutritional factors that affect the production and quality of wool. Degradation of feed proteins in the rumen prevents food supply to the sheep organism with large quantities of these amino acids. Proteins that avoid bacterial hydrolysis in the rumen (undegradable protein), increase the wool production through the increase in supplying the organism with amino acids, especially cystine, which is a limiting factor for the production of wool. Also, Jovanović et al. (2001) added that, the infusion of cystine into abomasum or blood can double the growth of wool, while the infusion of methionine increases the wool growth by providing sulfur for the synthesis of cysteine. 
Methionine is essential for the normal growth and development of mammals. This role derives from the unique participation of this amino acid or its derivatives in protein and polyamine synthesis and in the many transmethylation reactions. Furthermore, homocysteine is an obligatory co-substrate in the metabolism of both tissue folates and choline.

The main nutritional determination of wool growth is the amount and amino acid composition in the digestible protein reaching the small intestines (Reis, 1989). The protein of wool is significantly richer in cystine and serine and poor in lysine and methionine but the importance of these amino acids for fibre growth is not necessarily due to a proportionally high requirement of these amino acids for use as substrates in the synthesis of wool protein, but in their production of other proteins (Reis and Tunks, 1978).

The production of fibres from animals represents a small but economically important component of the global textile fibre market. A unique feature of animal fibres is that they largely consist of proteins. Wool fibres, for example, comprise from 50 to 100 spatially arranged keratins, which are encoded by discrete and exquisitely timed expression of genes within the wool follicle (Powell et al., 1991).

A number of studies on digestion of the ruminants have shown the process of synthesis of all the essential amino acids in the rumen (Trukhachev and Zlidnev, 2008). According to some researches, microbial protein is deficient in methionine and lysine. This assumption proves the need for further study of the influence of balanced amino acids to these diets on the growth, development and productive performance of the ruminants.

So, the aim of this study is to investigate the effect of rumen protected amino acids, methionine or/and lysine on the skin amino acids and wool follicle structures as well as the coat characteristics of Barki ewes.

\section{MATERIALS AND METHODS}

Skin and wool samples of 24 adult Barki ewes, aged 3-4 years with an average body weight of $28.95 \pm 1.37 \mathrm{~kg}$ raised in Maryout Research station located $35 \mathrm{~km}$ south west of Alexandria. The experiment was carried out from September 2016 to February 2017. The experimental animals were randomly allocated in four groups (6 ewes each) and fed on Berseem hay (Trifolium alexandrinum), offered add. Libitum plus concentrate feed mixture (14\% CP and $60 \%$ TDN) at a rate of $1 / 2$ $\mathrm{kg} / \mathrm{head} / \mathrm{day}$, which was composed of $50 \%$ cotton seeds cake, $18 \%$ wheat bran, $15 \%$ yellow corn, $11 \%$ rice polish, $3 \%$ molasses, $2 \%$ limestone and $1 \%$ common salt. Drinking water was provided twice daily.

The first group (control) fed only the control diet, the second group (Methionine) fed the control diet and rumen protected methionine $(7 \mathrm{~g} / \mathrm{head} / \mathrm{day})$, the third group (Lysine) fed the control diet and rumen protected lysine $(3 \mathrm{~g} / \mathrm{head} / \mathrm{day})$ and the fourth group (Methionine+Lysine) fed the control diet and mixture of $3 \mathrm{~g}$ Lysine and $7 \mathrm{~g}$ Methionine/head/day. The rumen protected amino acids in this experiment were imported from United Biomed Egypt.

Skin samples were taken from the mid side region which is considered as a standard follicle population area over the whole skin surface (Schleger and Turner, 1960). Skin specimens were fixed in calcium formol for about 24 hours (Barker, 1958), washed and left for 24 hours in distilled water, dehydrated in an ascending series of ethyl alcohol and embedded in paraffin wax. Sections of 6-8-micron thickness were stained using Haematoxylin and Eosin for histological examination (Drury and Wallington, 1980). Histochemically, Mercury bromophenol blue (Chapman, 1975) was used for the demonstration of the general proteins. To determine the amino acid in the skin samples, acid hydrolyzed amino acid by amid bond breakage was used according to Pellet and Young (1980) as follows: Diethyl ether was used for defatting $0.4 \mathrm{~g}$ from each skin sample. Five ml of $6 \mathrm{~N}$ hydrochloric acid was used to hydrolyze the sample in evacuated sealed test tube made of pyrex at $110^{\circ} \mathrm{C}$ for 24 hours. Hydrolysis was transferred to containers quantitavely at the end of the period. Hydrochloric acid was evaporated on water bath at $50-60^{\circ} \mathrm{C}$ to dryness. Five $\mathrm{ml}$ of distilled water was added to the hydrolysate and then evaporated to dryness to get rid of the excess of hydrochloric acid. Distilled water was added again until the excess of the hydrochloric acid removed completely, Samples were dried for obtaining dry film. The obtained dry film was dissolved in a known volume of sample dilution buffer (0.1N sodium acetate buffer, $\mathrm{pH}$ 2.2) and the solution was filtered through a $0.22 \mathrm{~mm}$ membrane filter and the samples stored frozen in a sealed vial until fractionation of amino acids by amino acid analyzer (Sykam Clarity Amino Acid Analyzer SW, Central Labe of Desert Research Center).

All histological and histochemical parameters were measured using Image analyzer software (Zen, 2012, Blue edition) and (device Carl-Zeiss micro-imaging G and bh) with lenses 10/0.847 and 40/0.65.

Wool fibre samples were taken from the animals of about 200-300 gm for each at the same time of getting the skin samples. Wool samples were classified into kemp, coarse and fine fibres. Clean wool production (CWP), fibre length growth rate (FGR) and crimp frequency (CF) were measured for all samples. Fibre cross sectional area was calculated by the following equation according to (Dun, 1958):

\section{FCSA $\left(\mu \mathrm{m}^{2}\right)=(\text { fiber diameter* } 0.5)^{2} \times 3.14$}

Fibre volume was calculated by the following equation according to (Brown and Turner 1968):

\section{FV $\left(\mathbf{m m}^{3}\right)=$ Fibre cross sectional area $*$ fibre length.}

The number of crimps along each un-stretched fibre was counted and the average fibre length was calculated and used to obtain the number of crimps per one centimeter. Sub samples, not less than 300 fibres, were classified into kemp, coarse and fine fibre categories; according to its coarseness and the percentage of medulla. Wool fibres contained very coarse fibers with medulla occupying more than $70 \%$ of the medullated fibre are classified as kemp and fibres contained medulla classified as coarse fibre, 
whereas other non-medullated fibres classified as fine fibres Guirgis (1973). Fibre length growth rate was calculated by dividing the fibre length on the number of the experimental days.

In order to calculate wool yield, each collected greasy wool samples was scoured according to Chapman (1960). Samples were preliminary dried by centrifuged dryer. Then fleeces were dried in a ventilated oven at $105^{\circ} \mathrm{C}$ and the yield percentage was estimated on a standard basis allowing only $14 \%$ residual matter. Both greasy and clean wool weight were recorded for each sample. A method suggested by Chapman (1960) was used to determine the weight of clean wool for every sample as follows:

\section{Weight of clean scoured and dry wool \\ Clean scoured yield $(\%)=$}

Greasy wool weight (grams)

SAS (2008) program, utilizing GLM procedure was used to analyze the obtained data and the differences between means within the different experimental groups were compared using Duncan's Multiple Range Test (Duncan, 1955).

\section{RESULTS AND DISCCIONS}

The wool follicle is a compound sheath which consists of an external connective tissue sheath derived from the dermis and an internal epithelial root sheath from the epidermis. This root sheath is subdivided into outer and inner components (Fig. 1). The outer component, the outer root sheath, possesses a single row of tall cells directly in relation to the glassy membrane. The inner root sheath is a keratinized sheath enveloping the growing wool root and, like the wool, it is pushed up by addition of cells from the bulb (Fig. 1)

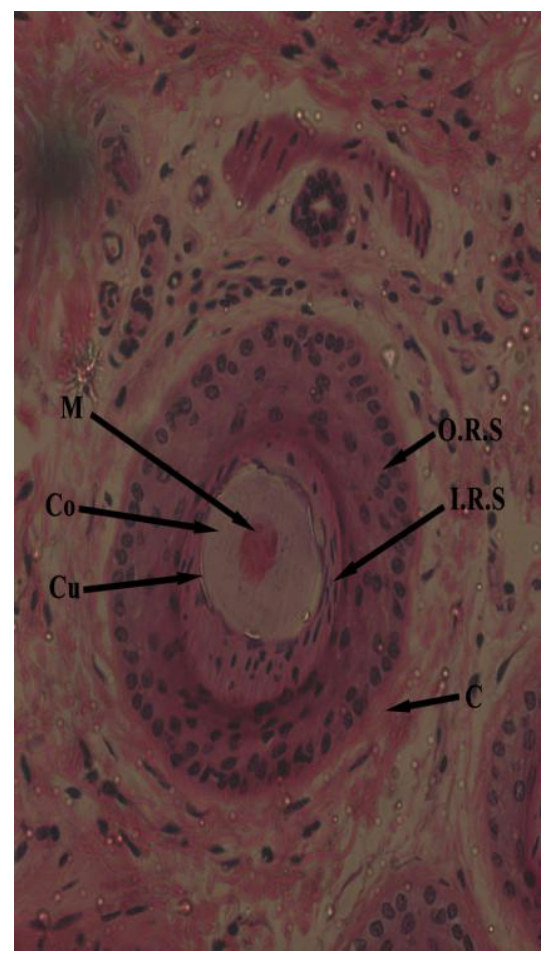

Figure (1): Transverse section showing different layers of a wool follicle and its fibre. C: connective tissue; IRS: inner root sheath; ORS: outer root sheath; Co: cortex; Cu: cuticle; M: medulla. (Hx. E., X 400).

In the present study, the external diameter and the wall thickness of both primary and secondary wool follicles were affected by different supplementations of rumen protected amino acids.

Data in table (1) demonstrated that there were increased values of the external diameter and the wall thickness of both primary and secondary wool follicles exceeded the control group. In the primary follicles, the use of rumen protected amino acids methionine or lysine recorded a significant increase in the mean values of the external diameter and wall thickness $(162.86 \pm 4.32$, $154.46 \pm 4.32)$ and $(87.54 \pm 3.57,77.78 \pm 3.57)$ rather than those of the control group $(135.31 \pm 4.32,52.58 \pm 3.57)$ respectively, while the mixture of methionine and lysine showed a non-significant increase (143.10 \pm 4.32 and $61.80 \pm 3.57)$ in comparison with the control group. On the other hand, the mean values of the internal diameter in the treated groups were slightly decreased than those in the control group (Table 1). In case of secondary follicles, the treated groups followed the same trend in which, methionine group had the greatest mean values of the external diameter and wall thickness (94.04 \pm 3.45 and $54.57 \pm 2.36)$ rather than the other two groups and the control group (Table 1). 
Citation: Naglaa. S. Badawy and W. A. Ramadan Studies on the skin and wool fibers of Barki sheep fed on protected lysine and methionine Res. J. Anim. \& Vet. Sci.10 (2): 28-37.DOI: $10.22587 /$ rjavs.2018.10.2.4

Table (1): Mean values $(\mu \mathrm{m} \pm \mathrm{SE}$ ) of primary and secondary wool follicle dimensions in the skin of Barki ewes fed different rumen protected amino acids.

\begin{tabular}{|c|c|c|c|}
\hline Follicle dimensions & Treatment & Primary follicle & Secondary follicle \\
\hline External diameter & Control & $135.31 \pm 4.32^{\mathbf{c}}$ & $82.67 \pm 3.45^{\mathbf{a}}$ \\
& Methionine & $162.86 \pm 4.32^{\mathbf{a}}$ & $94.04 \pm 3.45^{\mathbf{a}}$ \\
& Lysine & $154.46 \pm 4.32^{\mathbf{a b}}$ & $90.71 \pm 3.45^{\mathbf{a}}$ \\
& Lysine +Methionine & $143.10 \pm 4.32^{\mathbf{b c}}$ & $86.29 \pm 3.45^{\mathbf{a}}$ \\
\hline Internal diameter & Control & $82.04 \pm 3.93^{\mathbf{a}}$ & $45.64 \pm 1.51^{\mathbf{a}}$ \\
& Methionine & $76.18 \pm 3.93^{\mathbf{a}}$ & $39.79 \pm 1.51^{\mathrm{b}}$ \\
& Lysine & $78.44 \pm 3.93^{\mathbf{a}}$ & $41.65 \pm 1.51^{\mathbf{a b}}$ \\
\hline Wall thickness & Lysine + Methionine & $81.03 \pm 3.93^{\mathbf{a}}$ & $44.57 \pm 1.51^{\text {ab }}$ \\
& Control & $52.58 \pm 3.57^{\mathrm{b}}$ & $37.03 \pm 2.36^{\mathbf{c}}$ \\
& Methionine & $87.54 \pm 3.57^{\mathbf{a}}$ & $54.57 \pm 2.36^{\mathbf{a}}$ \\
& Lysine & $77.78 \pm 3.57^{\mathbf{a}}$ & $49.06 \pm 2.36^{\mathbf{a b}}$ \\
\hline
\end{tabular}

In each column, means of different experimental groups followed by different letters are significantly different $(\mathrm{P}<0.05)$

A close relationship exists between the intake of any particular diet and wool growth rate, the nature of the relationship being essentially linear provided sufficient time is allowed for the full extent of the follicular response to be registered and provided some account is taken of impact of increasing intake on digestibility of nutrients (Allden, 1979). However, the amounts and proportions of amino acids available to wool follicles have marked effects on the rate of wool growth and the influence of proteins on fibre growth will depend on the pathways operating in the follicle cells.

The oral coated methionine in the diet of the Barki ewes could significantly increase the diameter of primary and secondary wool follicles. This may be due to the importance of this amino acid to the wool follicles in which it is catabolized mainly through the S-adenosylmethionine pathway, and then diverted either "to the aminopropylation pathway and provides the aminopropyl group for synthesis of spermidine and spermine which are required for optimal growth in all cells and their physiological functions related to DNA, RNA and protein biosynthesis (Tabor and Tabor, 1984). Spermidine are essential for cell proliferation and growth of the cultured wool follicles" or to the transsulphuration pathway for synthesis of homocysteine which is used either for synthesis of cysteine that is required for the synthesis of the keratin proteins, which are produced in the keratogenous zone of the follicle or for remethylated to re-form methionine Benevenga et al. (1983). In addition, Nazem et al. (2013) also certify the increase in the wool follicle dimensions found in the animals supplemented with rumen protected methionine.

Downes et al. (1962) illustrated that, when radio labeled cysteine is introduced into the bloodstream and rapidly enters the cells in the keratogenous zone it diffuses across the endothelium of the capillaries surrounding the follicle and traverses the extracellular space. This may provide evidence that the rate of keratinization is the rate limiting process in fibre production and that the rate of cell division increases in response to the increased demand created by more rapid keratinization and hence the distal migration of cells.

Generally, wool follicles are function by "pull" (keratinization) as well as "push" (cell division) processes. (Hynd, 1989) mentioned that the supplementation with methionine increases the rate of cell division in wool follicles and also increases the wool growth by supplying sulphur for the synthesis of cysteine (Jovanović et al., 2001). This effect could be related to the stimulation of the mitotic activity in the follicle bulb as there is much evidence that sulfhydryl groups play an important role in mitosis (Reis et al., 1967). Other possible effects include increased production of co-factors important in protein and energy metabolism and stimulation of keratinization by the provision of sulfhydryl groups.

The experiments by Souri et al. (1996) using in vitro culture of hair follicles from Cashmere goats showed that providing cysteine without methionine resulted in a significant reduction in follicle growth and viability and methionine without cysteine supported growth of follicles to about 0.75 of that recorded with both methionine and cysteine present. This indicated that methionine plays a major role in addition to the provision of cysteine in the initiation of protein synthesis and in cell division. It could be concluded that the increase in wool growth with methionine supplementation is associated with the efficiency of the whole-body protein.

Dove and Robards (1974) also concluded that supplementation of methionine or cysteine given by abomasal infusion avoid degradation in the rumen and increase the wool growth rate of sheep consuming moderate amounts of roughage diets. On another point of view, rumen microbes degrading amino acids have meant that early attempts at supplementary feeding of amino acids resulted in few gains in wool production. This is due to the deamination of the acids in the rumen during the fermentation process of microbes (Chalupa, 1976). This deamination of amino acids into urea is nutritionally wasteful process with often more urea created than can be utilized by rumen bacteria. Coupled with this is the increased energy requirement to synthesis this urea $\mathrm{N}$ back into usable amino acids once it has been absorbed in the abomasums (Kajikawa et al., 2007). Presently amino acids can be fed in forms which bypass the rumen and reach the abomasums, where they are absorbed and used for protein synthesis (Staples et al., 1993).

In the present study, animals supplemented with rumen protected lysine followed those supplemented with methionine in the mean values of the external diameter and the wall thickness of both primary and secondary wool follicles (Table 1) and this is 
because the breakdown rates of methionine and lysine. Chalupa (1976) found that arginine and threonine are rapidly degraded, while lysine, phenylalanine, leucine and isoleucine are degraded at an intermediate rate. Methionine and valine are degraded more slowly and were considered the only real options for amino acid supplementation. On the other hand, the bulb cells of the wool follicle are more closely related to normal body cells and require lysine to support a high rate of cell division (Hynd, 1989). This is because it was incorporated into the germinative cells of the follicle bulb and the cells of the inner root sheath Thomas et al. (2014). The observations of (Reis, 1989) showed that, Provision of zein protein, which is lacking in both lysine and tyrosine markedly, depresses mitotic activity of bulb cell. But the supplementation of lysine to that protein can reverse such a detrimental effect (Reis and Tunks, 1978).

Protein is usually the most expensive part of the diet of sheep. The ultimate protein condition determining the rate of wool growth seems to be the concentration of essential amino acids in the tissue fluids around the follicle whereas the supply of amino acids to the animal is determined by the amount and kind of protein.

The distribution of the general proteins as demonstrated by bromophenol blue stain in the wool follicles of the different groups as shown in (Table 2 and figure 2) demonstrated that, both outer and inner root sheaths of the primary and secondary wool follicles possessed high amount of proteins.

Table (2): The distribution of general proteins in different root sheaths of skin wool follicles in Barki ewes fed different rumen protected amino acids (expressed as means of optical density values).

\begin{tabular}{|c|c|c|c|c|c|}
\hline Follicle type & Sheaths & control & Methionine & Lysine & Methionine+Lysine \\
\hline \multirow{2}{*}{$\begin{array}{c}\text { Primary } \\
\text { follicles }\end{array}$} & Outer & $0.853 \pm 0.01^{\mathrm{b}}$ & $0.907 \pm 0.01^{\mathrm{a}}$ & $0.871 \pm 0.01^{\mathrm{b}}$ & $0.868 \pm 0.01^{\mathrm{b}}$ \\
\cline { 2 - 6 } & Inner & $0.848 \pm 0.011^{\mathrm{b}}$ & $0.886 \pm 0.011^{\mathrm{a}}$ & $0.856 \pm 0.011^{\mathrm{b}}$ & $0.851 \pm 0.011^{\mathrm{b}}$ \\
\hline $\begin{array}{c}\text { Secondary } \\
\text { follicles }\end{array}$ & Outer & $0.818 \pm 0.01^{\mathrm{b}}$ & $0.870 \pm 0.01^{\mathrm{a}}$ & $0.859 \pm 0.01^{\mathrm{a}}$ & $0.856 \pm 0.01^{\mathrm{a}}$ \\
\cline { 2 - 6 } & Inner & $0.813 \pm 0.013^{\mathrm{b}}$ & $0.861 \pm 0.013^{\mathrm{a}}$ & $0.857 \pm 0.013^{\mathrm{a}}$ & $0.850 \pm 0.013^{\mathrm{ab}}$ \\
\hline
\end{tabular}

In each row, means followed by different letters are significantly different $(\mathrm{P}<0.05)$

By the harmony with the previous results, the experimental groups possessed a variable increase in the content of proteins rather than the control group. Both outer and inner root sheathes of primary wool follicles were affected significantly by the supplementation with rumen protected methionine $(0.907 \pm 0.01,0.886 \pm 0.011)$ respectively. These findings were followed by a non-significant increase in the group supplemented with lysine $(0.871 \pm 0.01,0.856 \pm 0.011)$ and then the group supplemented with the mixture of them $(0.868 \pm 0.01,0.851 \pm 0.011)$. In case of secondary follicles, the treated groups possessed a significant increase in the general proteins of the outer root sheath $(0.870 \pm 0.01,0.859 \pm 0.01$ and $0.856 \pm 0.01)$ in the groups of methionine, lysine and the mixture of them respectively rather than that of control group $(0.818 \pm 0.01)$.

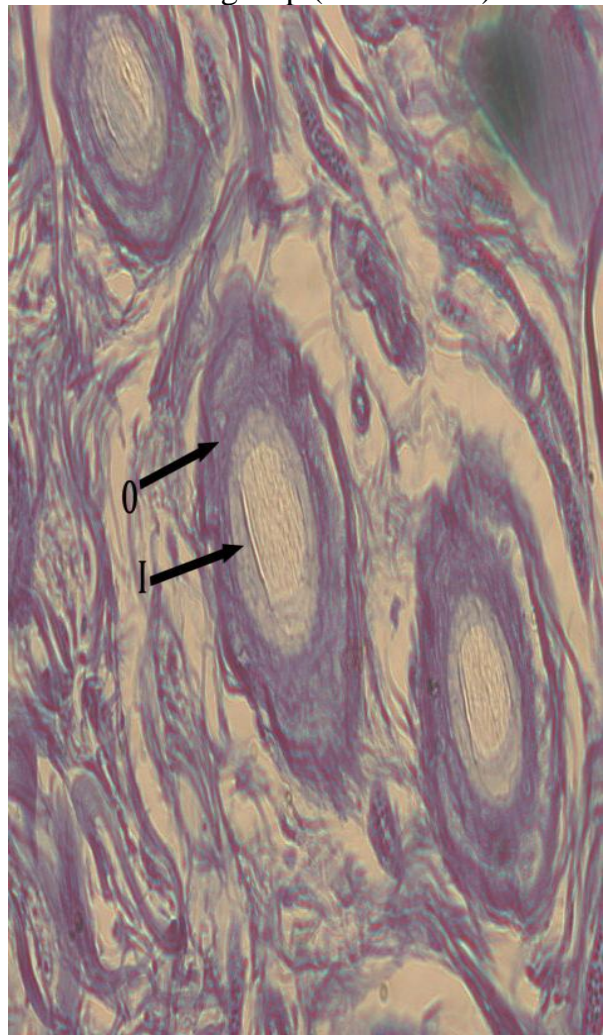

Figure (2): Transverse section in the wool follicle stained with bromophenol blue showing the distribution of the general proteins in the different follicle sheaths. I: inner root sheath, O: outer root sheath (X 400) 
Generally, the protein content was higher in the outer than that of the inner root sheath in both primary and secondary wool follicles. This might be probably due to the increased protein synthesis during cellular proliferation as indicated by Parmar et al. (1988) in goat. On the other hand, El-Sayed et al. (1998) observed a great difference in the presence of cysteine, cystine, $\mathrm{NH}_{2}$ group and tryptophan between the cortex and medulla of the hair fibre and they attributed that to their physical structure.

Available amino acids influenced the growth of animals by functioning as protein construction units (Miyasaki and Esser, 2009). Some of them may also be involved in the control of key metabolic processes, including protein synthesis. It is widely accepted that the major nutritional factors influencing wool growth are the amounts and proportions of amino acids available to the wool follicles, particularly the sulfur-amino acids, methionine and cyst(e)ine (Reis, 1979) and lysine, which are generally considered first- and possibly second-limiting respectively (Reis, 1989). Rogers (1964) reported that lysine is used primarily for synthesis of proteins in the inner root sheath.

On another point of view, the addition of protected amino acids (methionine or/and lysine) to the sheep nutrition showed a variable increase in the content of some essential and non-essential amino acids in the skin of the experimental groups rather than the control group (Table 3).

Table (3): Mean values $( \pm \mathrm{SE})$ of different amino acids content $(\mathrm{mg} / \mathrm{g})$ in the skin of Barki ewes fed different rumen protected amino acids.

\begin{tabular}{|c|c|c|c|c|}
\hline $\begin{array}{ll}\text { Groups } & \text { Groups } \\
\end{array}$ & control & Methionine & Lysine & Methionine+Lysine \\
\hline Asparagine & $0.101 \pm 0.31^{\mathrm{b}}$ & $1.352 \pm 0.31^{\mathrm{a}}$ & $0.201 \pm 0.31^{b}$ & $0.068 \pm 0.31^{\mathrm{b}}$ \\
\hline Threonine & $0.058 \pm 0.12^{\mathrm{b}}$ & $0.534 \pm 0.12^{\mathrm{a}}$ & $0.184 \pm 0.12^{\mathrm{ab}}$ & $0.075 \pm 0.12^{\mathrm{b}}$ \\
\hline Serine & $0.057 \pm 0.18^{b}$ & $0.744 \pm 0.18^{\mathrm{a}}$ & $0.159 \pm 0.18^{\mathrm{b}}$ & $0.098 \pm 0.18^{b}$ \\
\hline Glutamic & $0.130 \pm 0.46^{\mathrm{b}}$ & $1.857 \pm 0.46^{\mathrm{a}}$ & $0.095 \pm 0.46^{\mathrm{b}}$ & $0.037 \pm 0.46^{b}$ \\
\hline Glycine & $0.360 \pm 0.77^{b}$ & $3.515 \pm 0.77^{\mathrm{a}}$ & $1.919 \pm 0.77^{\mathrm{ab}}$ & $1.160 \pm 0.77^{\mathrm{ab}}$ \\
\hline Alanine & $0.244 \pm 0.12^{\mathrm{c}}$ & $1.981 \pm 0.12^{\mathrm{a}}$ & $1.459 \pm 0.12^{\mathrm{b}}$ & $1.153 \pm 0.12^{b}$ \\
\hline Cystine & $0.029 \pm 0.02^{\mathrm{c}}$ & $0.434 \pm 0.02^{\mathrm{a}}$ & $0.151 \pm 0.02^{b}$ & $0.147 \pm 0.02^{b}$ \\
\hline Valine & $0.061 \pm 0.06^{\mathrm{C}}$ & $0.599 \pm 0.06^{\mathrm{a}}$ & $0.352 \pm 0.06^{\mathrm{b}}$ & $0.263 \pm 0.06^{b}$ \\
\hline Methionine & $0.010 \pm 0.05^{b}$ & $0.189 \pm 0.05^{\mathrm{a}}$ & $0.038 \pm 0.05^{\mathrm{ab}}$ & $0.015 \pm 0.05^{b}$ \\
\hline IsoLeucine & $0.039 \pm 0.03^{\mathrm{c}}$ & $0.391 \pm 0.03^{\mathrm{a}}$ & $0.214 \pm 0.03^{b}$ & $0.162 \pm 0.03^{b}$ \\
\hline Leucine & $0.111 \pm 0.07^{\mathrm{c}}$ & $1.062 \pm 0.07^{\mathrm{a}}$ & $0.587 \pm 0.07^{\mathrm{b}}$ & $0.443 \pm 0.07^{b}$ \\
\hline Tyrosine & $0.018 \pm 0.02^{\mathrm{c}}$ & $0.241 \pm 0.02^{\mathrm{a}}$ & $0.108 \pm 0.02^{b}$ & $0.086 \pm 0.02^{b}$ \\
\hline Phenylalanine & $0.083 \pm 0.10^{\mathrm{b}}$ & $0.494 \pm 0.10^{\mathrm{a}}$ & $0.402 \pm 0.10^{\mathrm{ab}}$ & $0.280 \pm 0.10^{\mathrm{ab}}$ \\
\hline Histidine & $0.086 \pm 0.07^{\mathrm{c}}$ & $0.743 \pm 0.07^{\mathrm{a}}$ & $0.442 \pm 0.07^{\mathrm{b}}$ & $0.332 \pm 0.07^{\mathrm{b}}$ \\
\hline Lysine & $0.121 \pm 0.13^{b}$ & $0.872 \pm 0.13^{\mathrm{a}}$ & $0.588 \pm 0.13^{\mathrm{a}}$ & $0.477 \pm 0.13^{\mathrm{ab}}$ \\
\hline Arginine & $0.344 \pm 0.50^{b}$ & $2.539 \pm 0.50^{\mathrm{a}}$ & $2.232 \pm 0.50^{\mathrm{a}}$ & $1.626 \pm 0.50^{\mathrm{ab}}$ \\
\hline Proline & $0.278 \pm 0.24^{\mathrm{c}}$ & $2.394 \pm 0.24^{\mathrm{a}}$ & $1.139 \pm 0.24^{\mathrm{b}}$ & $1.042 \pm 0.24^{b c}$ \\
\hline
\end{tabular}

In each row, means followed by different letters are significantly different $(\mathrm{P}<0.05)$

Data presented in table (3) showed that, animals had rumen protected methionine recorded a significant $(\mathrm{P}<0.05)$ increase in all amino acid contents in their skin samples followed by those supplemented with rumen protected lysine and then animals which had the mixture of methionine and lysine.

The protein synthesis in the skin has also been shown to be responsive to changes in amino acid supply (Harris et al., 1997). And there is a close relationship between the rate of protein synthesis in the skin and the rate of wool growth (Liu et al., 1998). The present results demonstrate that, adding rumen protected methionine to the diet of group two increases the rate of protein synthesis in the skin. This was insured by Liu et al. (2000) who stated that supplementation with methionine increases the rate of protein synthesis in the skin and the expression of some genes in follicles encoding an intermediate filament keratin protein and keratin intermediate filament associated proteins were increased by the infusion of $3 \mathrm{~g} / \mathrm{d}$ of methionine for a period of 7 days. Generally, methionine has a role in initiating synthesis of any protein and it serves as a precursor of homocysteine and cysteine sulfur. In addition, the whole-body protein synthesis was increased with the supplementation of rumen protected methionine in Japanese goats (Muramatsu et al., 1994) that is because the infusion of methionine into the rumen can increase the protein synthesis of rumen bacteria. Sulphur containing amino acids from bacterial proteins and those infused into the abomasums stimulate the anabolism of animals. Lambs fed feed additives contain high ratio of protein with methionine and cysteine improve health status, blood parameters and more blood supply to the skin causing an increase in the wool follicle activity and efficiency (Pelitte and Sauvaire, 1995 and Al-Jassir, 1992).

(Mata et al., 1995) concluded that, Measurements of glutathione, a tripeptide containing cysteine, glycine and glutamate found in red blood cells and skin, could be of significant benefit in defining responses to supplements of sulfur and sulfur amino acids (methionine). Also, glutathione has been shown to have a specific role as a cysteine reservoir, and it is used for the synthesis of wool growth in sheep. In our study supplementation with methionine, lysine and the mixture of them have a variable effect on the content of several amino acids in animals skin, Table (3) illustrated that both glysine and glutamic acid were increased significantly by the addition of methionine. While, leucine, tyrosine and phenylalanine recorded significantly higher values in all 
experimental groups in comparison with the control one. Leucine serves as an energy source and is a regulator of protein turnover and it enhances the uptake of phenylalanine (which is a forerunner of tyrosine, the anti-depressant dopamine, norepinephrine, epinephrine and the skin pigment), and tryptophan and it stimulates protein synthesis, whereas its metabolite, $\alpha$-ketoisocaproate, inhibits protein catabolism (Bender, 1984). Table (3) revealed that skin content of arginine was greater significantly in the methionine and lysine groups than that of the control group. It is a precursor to synthesis of polyamines, which regulate DNA and protein synthesis, cell proliferation and differentiation and regulation of gene expression (Kwon et al., 2003) and it is also a precursor to nitric oxide which regulates blood flow that provide excess nutrient for wool growth (Martin et al., 2001).

On the other hand, the treated group with lysine showed a variable increase in the content of different amino acids in the skin samples and this was attributed to its synthesizes hydroxylysine by lysylhydroxylase reaction called hydroxylation. As is known, collagen is the most abundant family of proteins in the extracellular matrix of connective tissues which include skin (Halper and Kjaer, 2014). Collagen is cross linked to form fibrous proteins based on aldehyde formation from the amine side chains of lysine or hydroxylysine residues, and it is lysyl oxidase, an enzyme, that converts the amine side chains of the lysine or hydroxylysine residues into aldehydes (Eyre et al., 1984). Also, hydroxylysine represents special sites for the attachment of carbohydrates in collagen (Gelse et al., 2003). In addition, collagen plays very important roles for defining the structural integrity and physiological functions of the extracellular matrix of connective tissues (Wang et al, 2013).

Various mixtures containing methionine stimulated wool growth. The importance of methionine and lysine in wool growth is in their ability to be directed away from the fibre follicle (wool) and be used in the synthesis of inner root sheath proteins, the area of the follicle of fibre where the growth of fibre is initiated (Rogers, 1964). However, the addition of lysine to the diet of wethers significantly increased all aspects of wool growth (Reis and Tunks, 1978). This is related to its high content in histone proteins which are active in cell division (Brusch, 2012).

Fibre diameter is the most important character affecting spinning count and the economic value of wool. The present study indicated that supplementation with rumen protected methionine recorded an increase in the diameters of wool fibres produced from both primary and secondary follicles $(68.13 \pm 3.54$ and $33.61 \pm 2.76)$ rather than those of the other two groups while the control group recorded the finest fibres $(61.41 \pm 3.54$ and $28.86 \pm 2.76)$.

Table (4): Mean diameter values and medulla thickness ( $\mu \mathrm{m} \pm \mathrm{SE}$ ) of the fibres produced from both primary and secondary wool follicles in the skin of Barki ewes fed different rumen protected amino acids.

\begin{tabular}{|c|c|c|c|c|}
\hline Groups & Control & Methionine & \multicolumn{1}{l|}{ Lysine } & Methionine+Lysine \\
\hline Primary fibres & $61.41 \pm 3.54^{\mathrm{a}}$ & $68.13 \pm 3.54^{\mathrm{a}}$ & $63.57 \pm 3.54^{\mathrm{a}}$ & $63.02 \pm 3.54^{\mathrm{a}}$ \\
\hline Secondary fibres & $28.86 \pm 2.76^{\mathrm{a}}$ & $33.61 \pm 2.76^{\mathrm{a}}$ & $31.01 \pm 2.76^{\mathrm{a}}$ & $29.53 \pm 2.76^{\mathrm{a}}$ \\
\hline Medulla thickness & $24.77 \pm 1.17^{\mathrm{c}}$ & $41.00 \pm 1.17^{\mathrm{b}}$ & $39.00 \pm 1.17^{\mathrm{b}}$ & $35.95 \pm 1.17^{\mathrm{b}}$ \\
\hline
\end{tabular}

In each row, means followed by different letters are significantly different $(\mathrm{P}<0.05)$

Our results are in agreement with (Mata et al., 1995) who found that methionine as Lactate form significantly increased fibre diameter. The increased diameter of Mohair fibres following methionine supplementation was due to the suggested role of an increased intermediate filament-associated protein fraction in producing a greater volume of cells of the hair cortex (Galbraith, 2000). In addition, (Reis et al., 1990) showed that, methionine was performed some specific function, perhaps in wool protein synthesis or cell division. Also, Sahlu and Fernandez (1992) found that methionine increased the yield and diameter of mohair in Angora goats. The diameter of fibres from Angora rabbit was increased by methionine supplementation in the experiment of Herrmann et al. (1996)

On the other hand, Qi et al. (1994) reported that, lysine supply may alter fibre diameter. (Reis, 1989) showed that, Provision of zein protein, which is lacking in both lysine and tyrosine markedly depresses fibre diameters, but the supplementation of lysine to that protein can reverse such a detrimental effect (Reis and Tunks, 1978). They also added that omission of lysine from a mixture of 13 amino acids infused into the abomasum of Merino sheep depressed fibre diameter while, Ismailov et al. (2017) concluded that the wool productivity of the fine-wool sheep was higher by $7.8 \%$.

On another point of view, (Youssef, 2017) recorded that the wool fibre length increased significantly with the increment of the fibre diameter by adding different rumen protected amino acids. The previous findings are in harmony with the increased values in wool yield (as represented by increased fibre cross sectional area, fibre volume and fibre length growth rate) in the different experimental groups rather than the control group, as shown in table (5).

In the present study, the relative width of the medulla was increased with the increase in the diameter of the wool fibres. Table (4) indicated that the medulla thickness increased significantly by the supplementation with amino acids rather than the control group. Methionine group which has the largest fibre diameter $(68.13 \pm 3.54)$ has the greatest medulla (41.00 \pm 1.17$)$ while, the control group which has the smallest fibre diameter (61.41 \pm 3.54$)$ also has the smallest medulla thickness $(24.77 \pm 1.17)$. The intermediate medulla thicknesses were recorded in the lysine group followed by the group supplemented with the mixture of methionine and lysine.

Methionine group was lower significantly than control group $(\mathrm{P}<0.05)$ in crimp frequency and fine fibers\%, while there was no significant difference between lysine group and mixture of lysine and methionine group compared with the control group. Reis and Gillespie (1985) found that administration of the methionine analogue methoxinine (O-methyl-DL-homoserine) to sheep substantially changed the composition of wool; in addition wool fibres were weakened and the staple crimp frequency was 
reduced for a prolonged period. The proportions of high-tyrosine proteins were reduced by $40-45 \%$ whereas the high-sulfur proteins were usually slightly increased. The content of high-tyrosine proteins in wool was still depressed in most sheep 70 days after dosing with methoxinine. Campbell et al. (1975) stated that when the nutritional level of sheep is restricted, the staple crimp frequency of the resultant fleece increases substantially whereas the cystine and high-sulphur protein contents decrease. This is in marked contrast to the direct relationship between crimp frequency and cystine content among sheep. These observations can be reconciled by assuming that variations in crimp frequency are attributable slowly to a combination of follicle shape and fibre length growth rate without recourse to the more generally accepted theories relating to the proportion and distribution of orthoand para cortical cells in the fibre cortex. The major portion of the decrease in the cystine content of high-crimp wools is due to the decreased synthesis of a specific protein fraction, ultra-high-sulphur protein. Low-crimp wools do not appear to contain this protein fraction and in this respect they may differ from high-crimp wools.

Table (5): Mean values ( \pm SE) of some wool characteristics of Barki ewes fed different protected amino acids.

\begin{tabular}{|c|c|c|c|c|}
\hline Parameter & Control & Methionine & Lysine & Methionine+Lysine \\
\hline $\begin{array}{c}\text { Fiber cross sectional } \\
\text { area, } \boldsymbol{\mu m}^{\mathbf{2}}\end{array}$ & $691.95 \pm 112.42^{\mathrm{b}}$ & $1126.91 \pm 112.42^{\mathrm{a}}$ & $720.22 \pm 112.42^{\mathrm{b}}$ & $854.23 \pm 112.42^{\mathrm{ab}}$ \\
\hline Fiber volume, $\mathbf{~ m m}^{\mathbf{3}}$ & $0.050 \pm 0.019^{\mathrm{c}}$ & $0.152 \pm 0.019^{\mathrm{a}}$ & $0.092 \pm 0.019^{\mathrm{bc}}$ & $0.112 \pm 0.019^{\mathrm{ab}}$ \\
\hline $\begin{array}{c}\text { Fiber length growth } \\
\text { rate, cm }\end{array}$ & $0.33 \pm 0.16^{\mathrm{b}}$ & $1.34 \pm 0.16^{\mathrm{a}}$ & $1.31 \pm 0.16^{\mathrm{a}}$ & $1.32 \pm 0.16^{\mathrm{a}}$ \\
\hline crimp frequency/cm $^{\text {Fine fibers\% }}$ & $3.92 \pm 0.30^{\mathrm{a}}$ & $2.75 \pm 0.30^{\mathrm{b}}$ & $3.5 \pm 0.30^{\mathrm{ab}}$ & $3 \pm 0.30^{\mathrm{ab}}$ \\
\hline Coarse fibers\% & $59.38 \pm 4.37^{\mathrm{a}}$ & $42.37 \pm 4.37^{\mathrm{b}}$ & $54.77 \pm 4.37^{\mathrm{ab}}$ & $57.87 \pm 4.37^{\mathrm{a}}$ \\
\hline Kemp fibers\% & $7.17 \pm 2.71^{\mathrm{b}}$ & $16.98 \pm 3.43^{\mathrm{a}}$ & $35.84 \pm 3.43^{\mathrm{a}}$ & $32.02 \pm 3.43^{\mathrm{a}}$ \\
\hline $\begin{array}{c}\text { Clean wool } \\
\text { production/10 } \mathbf{1 0}\end{array}$ & $5.86 \pm 0.54^{\mathrm{b}}$ & $8.31 \pm 0.54^{\mathrm{a}}$ & $9.40 \pm 2.71^{\mathrm{ab}}$ & $10.11 \pm 2.71^{\mathrm{ab}}$ \\
\hline
\end{tabular}

In each row, means followed by different letters are significantly different $(\mathrm{P}<0.05)$

Methionine group was lower significantly than control group $(\mathrm{P}<0.05)$ in fine fibres\% while the opposite trend was observed in kemp fibres\% and it was higher than other groups but with insignificant values in coarse fibers\%. Nazem et al. (2013) found that the oral coated methionine in the diet of the goat mothers during the first two months of infancy can significantly increase the diameter of primary and secondary follicles and their dermal papilla in the mothers and their treated kids. It also can increase the number of secondary follicles in the kids.

Table (5) revealed that addition of methionine resulted in significantly $(\mathrm{P}<0.05)$ higher clean wool production per $10 \mathrm{~cm}^{2}$ compared with the other groups, that is due to increased values of the diameters and lengths of fibres happened by methionine supplementation. Whereas addition of lysine and both methionine and lysine groups had non-significant increased values compared with control group. Stephenson et al. (1991) found that methionine tended to increase wool productivity. Moreover, (Helal, 2004) recorded that, the infusion of methionine tended to increase wool production by $20 \%$ compared with the control group. Clean wool yield takes the same trend of clean wool per studied area. In the same way, Galbraith (2000) reported that methionine stimulated raw fibre yields of both Angora and Cashmere goats. Also, Sahlu and Fernandez (1992) revealed that grease and clean mohair yields were increased with methionine infusion.

Conclusively, the present work accomplished an effective beneficial use of the rumen protected amino acids (methionine or/and lysine) in the enhancement of the wool follicle activity and consequently the changeable characteristics of the fibre produced by them which participate in the magnification of the Barki sheep performance and productivity.

\section{REFERENCES}

Al-Jassir, M.S. (1992). Chemical compositions and micro flora of black cumin. Nigella sativa L. seeds growing in Saudi Arabia. Food Chemistry. ; 45(4): 239-242.

Allden, W.G. (1979). Feed intake, diet composition and wool growth. In Physiological and environmental Limitations to Wool Growth. (Eds. J.L. black and P.J. Reis) pp. 61-78. (University of new England Publishing Unit: Armidale).

Barker, J.R. (1958).Principles of biological technique. London, Methuen, New York, John Wiley. Bancroft. J.D.

Bender, D.A. (1984). Amino Acid Metabolism. (2 $2^{\text {nd }}$ Ed.). John Wiley\& Sons, Chichester, U.K.

Benevenga, N.J.; Radcliffe, B.C. and Egan, A.R. (1983) Tissue metabolism of methionine in sheep. Australian Journal of Biological Sciences 36, 475-485.

Brown, G.H. and Turner, H.N. (1968). Response to selection in Australian Merino sheep. 11 estimates of phenotypic and genetic parameters for some production traits in Merino ewes and an analysis of the possible effects of selection on them. Aust. J. Agric. Res. 19, 303-322.

Brusch, H. (2012). Histones and other nuclear proteins. 
Citation: Naglaa. S. Badawy and W. A. Ramadan Studies on the skin and wool fibers of Barki sheep fed on protected lysine and methionine Res. J. Anim. \& Vet. Sci.10 (2): 28-37.DOI: 10.22587/rjavs.2018.10.2.4

Campbell, M.E.; Whiteley, K.J.; Gillespie, J.M. (1975). Influence of nutrition on the crimps rate of wool and the type and proportion of constituent proteins. Aust. J. Biol. Sci., 28(4): 389-97.

Chalupa, W. (1976). Degradation of Amino Acids by the Mixed Rumen Microbial Population. JOURNAL OF ANIMAL SCIENCE. Vol. 43, No. 4

Chapman, D.M. (1975). Dichromation of bromophenol blue, with an improvement in the mercuric bromophenol blue technique for protein. Stain Technology. 50, 25-30.

Chapman, R.E. (1960). In the biology of the fleece, edited by A.S. Fraser, and B.F. Short, Animal Research Laboratories Technical Paper No. 3. CSIRO, Australia.

Dove, H. and Robards, G.E. (1974). Effect of abomasal infusions of methionine, casein, and starch plus methionine on the wool production of Merino wethers fed on lucerne or wheaten chaff. Australian Journal of Agricultural Research. 25,945-56.

Downes, A.M.; Lyne, A.G. and Clarke, W.H. (1962). Radioautographic studies of the incorporation of [35S] cystine into wool. Aust. J. Biol. Sci. 17:140-153.

Drury, R.A.B. and Wallington, E.A. (1980).Carleton's histological technique. 4th. Ed. Oxford University press., Oxford, New York, Toronto.

Dun, R.B. (1958). The influence of selection and plane of nutrition on the components of fleece weight in Merino sheep. Australian Journal of Agricultural Research 9(6) 802 - 818.

Duncan, D.B. (1955). Multiple Range and Multiple F Test. Biometric, 11:1-42.

El-Sayed, N.A. ; El-Samannoudy, F.A. ; El-Awy, S.A. and Abdou, A.S. (1998). Effect of age and season on the histochemical structure of the growing hair fibre of the goat. Desert Inst. Bull. Egypt, 48: No. 2, 427-452.

Eyre, D.R.; Paz, M.A. and Gallop, P.M. (1984). Cross-linking in collagen and elastin. Annu Rev Biochem 53:717-748

Galbraith, H. (2000). Protein and sulphur amino acid nutrition of hair fibre-producing Angora and cashmere goats. Livestock Production Science 64, 81-83.

Gelse, K.1.; Pöschl, E. and Aigner, T. (2003). Collagens--structure, function, and biosynthesis. Adv Drug Deliv Rev. 55 (12): 1531-1546.

Guirgis, R.A. (1973). The study of variability in some wool traits in a coarse wool breed of sheep. J. Agic. Sci. Camb., 80: 233238.

Halper, J.1. and Kjaer, M. (2014). Basic components of connective tissues and extracellular matrix: elastin, fibrillin, fibulins, fibrinogen, fibronectin, laminin, tenascins and thrombospondins. Adv Exp Med Biol. 802:31-47.

Harris, P.M.; Sinclair, B.R.; Treloar, B.P. and Lee, J. (1997). Short-term changes in whole body and skin sulfur aminoacid metabolism of sheep in response to supplementarycysteine. Australian Journal of Agricultural Research 48:137-146.

Helal, A. (2004). Effect of sulfur supplementation on wool production in Barki sheep. Ph. D. Thesis, Fac. Agric., Cairo Univ., Giza, Egypt.

Herrmann, H.; Hanter, M.; Brettel, M.; Muller, S.A.; Goldie, K.N.; Fedtke, B.; Lustig, A.; Franke, W.W. and Aebi, U. (1996). Structure and assembly properties of the intermediate filament protein vimentin: the role of its head, rod and tail domains. J. Mol Biol. 264, 933-953.

Hynd, P.I. (1989). Factors influencing the cellular events in the woolfollicle. Pages 169-184 in The Biology of Wool and Hair Growth.G. E. Rogers, P. J. Reis, K. A. Ward, and R. C. Marshall, ed.Chapman and Hall, London, UK.

Ismailov, I.F.; Tregubova, N.V.; Kochkarov, R.H.; Morgunova, A.V. and Drizhd, N.A. (2017). The relationship of amino acid metabolism with productivity of growing young sheep. Proceedings of the 8th International Scientific Conference Rural Development 2017.

Jovanovic, R.; Dujic, D. and Glamocic, D. (2001). Ishrana domaćih životinja, eds., Stylos, Novi Sad, pp. 713.

Kajikawa, H.; Tajima, K.; Mitsumori, M. and Takenaka, A. (2007). Effects of amino nitrogen on fermentation parameters by mixed ruminal microbes when energy or nitrogen is limited. Animal Science Journal, 78(2), 121-128.

Kwon, H.; Wu, G.; Bazer, F.W. and Spencer, T.E. (2003). Developmental changes in polyamine levels and synthesis in the ovine conceptus. Biol. Repord. 69, 1626-1634.

Liu S.M.; Mata, G.; Figliomeni, S.; Powell, B.C.; Nesci, A. and Masters, D.G. (2000). Transsulphuration, protein synthesis rate and follicle mRNA in the skin of young Merino lambs in response to infusions of methionine and serine. British Journal of Nutrition 83, 401-409.

Liu, S.M.; Mata, G.; O'Donoghue, H. and Masters, D.G. (1998). The influence of live-weight, live-weight change and diet on protein synthesis in the skin and skeletal muscle in young Merino sheep. British Journal of Nutrition 79:267-274.

Martin, M.J.; Jimenez, M.D. and Motilva, V. (2001). New issues about nitric oxide and its effects on the gastrointestinal tract. Curr. Pharm. Des. 7(10): 881-908.

Mata, G.; Masters, D.G.; Buscall, D.; Street, K. and Schlink, A.C. (1995). Responses in Wool Growth, Liveweight, glutathione and amino acids, in Merino wethersfedincreasing amounts of methionine protectedfrom degradation in the rumen.Aust. J. Agric. Res., 1995, 46, 1189-1204

Miyasaki, M. and Esser, K.A. (2009). Cellular mechanisms regulating protein synthesis and skeletal muscle hypertrophy in animals. Journal of Applied Physiology 106, 1367-1373.

Muramatsu, T.; Hatano, T.; Ueda, Y.; Furuse, M. and Okumura, J. (1994). Whole-body protein turnover in goats enhanced by supplementing a diet with rumen protected methionine. Asian-Australian Journal of Animal Sciences 7, 279-288. 
Nazem, M.N.; Rezaian, M.; Adib Moradi, M.; Asadi Fuzi, M.; Kyaei, S.M.M. and Razavi, E.P. (2013). The effect of oral administration of coated methionine on the female goats and suckling kids hair follicles: a histomorphometrical approach. Journal of Veterinary Research 2013 Vol.68 No.1 pp.61-68.

Parmar, M.L.; Sinha, R.D.; Parasad, G. and Prasad, J. (1988). Histochemical studies on hair follicles and sebaceous and sweat glands in goat. Ind. J. Anim Sci., 58 (7): 789-791.

Pelitte, P.and Sauvaire, Y.D. (1995). Effect of fenugreek seeds on feeding behavior in the rats. Metabolic endocrine correlates. Pharmacol Biochem. Behav. ; 45:362-374.

Pellet, P.L. and Young, V.R. (1980). Nutritional evaluation of protein foods. Published by the United Nation University.

Powell, B.C.; Nesci, A. and Rogers. G.E. (1991). Regulation of keratingene expression in hair follicle differentiation. Ann. N. Y. Acad.Sci. 642:1-20.

QI, K.; Lupton, C.J. and Owens, F.N. (1994). A review of amino acid requirements for fiber growth of sheep and Angora goats. Sheep \& Goat Res. J. Vol, 10, No. 3: 160-167.

Reis, P.J. (1979). Effects of amino acids on the growth and properties of wool. In: Black J.L. \& Reis P.J. (ed.) Physiological and Environmental Limitations to Wool Growth. University of New England Publishing Unit, Armidale, Australia, pp. 223242.

Reis, P.J. (1989). The influenceof absorbed nutrientson wool growth. In:The biology of wool and hair. Eds. Rogers, G.E., Reis, P.J., Ward, K.A.\&Marshall, R.C., Chapman and Hall, London.p. 185

Reis, P.J. and Gillespie, J.M. (1985). Effects of phenylalanine and analogues of methionine and phenylalanine on the composition of wool and mouse hair. Aust. J. Biol. Sci. 38(2): 151-163.

Reis, P.J. and Tunks, D.A. (1978). Effects on wool growth of the infusion of mixtures of amino acids into the abomasum of sheep. The J. of Agric. Sci. 90(1): pp 173-183.

Reis, P.J.; Tunks, D. and Munro, S. (1990). Effects of the infusion of amino acids into the abomasum of sheep, with emphasis on the relative value of methionine, cystein and homocysteine for wool growth. The J. of Agric. Sci., 114(1): 59-68.

Reis, P.J.; Tunks, D.A.; Williams, O.B. and Williams, A.J. (1967). A relationship between sulfur content of wool and wool production by Merino sheep. Aust. J. Biol. Sci. 20: 153-163.

Rogers, G. E. (1964). Isolation and properteis of inner sheath cells of hair follicles. Exp. Cell Res. 33: 264-276.

Sahlu, T. and Fernandez, J.M. (1992). Effect of intraperitoneal administration of lysine and methionine on mohair yield and quality in Angora goats. Journal of Animal Science 70, 3188-3193.

Sas, (2008). User's Guide. Statistics. Version 9.2 edition. SAS Institute Inc., Cary, NC.

Schleger, A.V. and Turner, H.G. (1960). Analysis of coat characteristics of Cattle. Aust. J. Agric. Res. 12, $176-202$.

Souri, M.; Galbraith, H. and Scaife, J.R. (1996). The role of methionine and cystine in growth and viability of secondary follicles of the Cashmere goat in vitro. Animal Science 62, 669.

Staples, L.D.; McPhee, S.R.; Williams, A.H. and Johnson, R.J. (1993). The application of new technology for the protection of amino acids to improve wool production and body growth in sheep. In: Recent advances in animal nutrition in Australia. Ed. Farrell, D .J., Dept. Of Biochemistry, Microbiologyand Nutrition, University of New England, Armidale,N .S.W.p . 22.

Stphenson, R.G.A.; Suter, G.R. and Howitt, C.J. (1991). Wool growth responses to DL-methionine administration and factors affecting the value of supplementation. Aust. J. Exp. Agric., 31: 471-477.

Tabor, C.W. and Tabor, H. (1984). Polyamines. Annual Review on Biochemistry. 53, 749-790.

Thomas, N.; Tivey, D.R.; Penno, N.M.; Nattrass, G. and Hynd, P.I. (2014). Characterization of transport systems for cysteine, lysine, alanine, and leucine in wool follicles of sheep.Journal of Animal Science - Ruminant Nutrition Vol. 85 No. 9 , pp. 2205-2213.

Trukhachev, V. and Zlidnev, N. (2008). A requirement of highly productive fine-fleece sheep is in amino acids. Researchproduction Journal of Sheep, Goat and Woolen Business, Vol. 3, pp. 48-49.

Wang, T.X.; Yin, Z.H.; Zhang, W.; Peng, T. and Kang, W.W. (2013). Chemical constitiuents from psoralea corylifolia and their antioxidant alpha-glucosidase inhibitory and antimicrobial activity. China J. of Chinese material Medica 38(14): 23182333.

Wu, G.; Bazer, F.W.; Dai, Z.L.; Li, D.F.; Wang, J.J. and Wu, Z.L. (2014). Amino acid nutrition in animals: protein synthesis and beyond. Annu Rev Anim Biosci. 2014; 2:387-417.

Youssef, A.H. (2017). Effect of adding some protected amino acids on some wool characteristics in Barki sheep. M.Sc. Mansoura University. 